\title{
Interim - Management as a new Form of Employment - opportune in a globalized context
}

\author{
Mihaela-Emilia MARICA \\ Bucharest University of Economic Studies, Bucharest, Romania \\ mihaela.marica@drept.ase.ro
}

\begin{abstract}
Non-standard forms of employment have become current practice in most European legal systems, by virtue of their positive effects on labor flexibility - beneficial to both employers and employees. From a company's perspective and interests, regarding the current context of labour relations, a new approach is needed and highly recommended. In an unpredictable business environment, only those innovative companies which have proved able to identify business opportunities and adjust to change have remained competitive. Therefore, the interim management program - as a new type of employment - brings forth an extensive potential for development. Since Romania is a country where this contractual model is relatively little known, this paper addresses some of the most obvious elements of this atypical contractual arrangement, which most authors deem very appropriate in the context of globalization. Our comparative approach seeks to identify various legislative perspectives on interim management and the conclusions of our research suggest the usefulness of the introduction the interim management model to the national labor market. The comparison of this form of flexible employment and other forms used in Romanian companies has been conducted.
\end{abstract}

Keywords: interim management, new forms of work, globalization, organizational crisis, atypical work.

\section{Introduction}

The expression „new employment forms” or the more popular one „flexible forms of work" has already become omnipresent and can be found in the most diverse legal systems in the world. The new work arrangements differ from the classical employment contracts as they do not have all the characteristics of regular employment relationships and they are intended to meet the increasing need for labor flexibility. (Hevestone D, 2010). As per the European documents, as well as the relevant doctrine, the conceptual difference between "atypical labor agreements" and "very atypical agreements" is a very clear one. In a 2010 report, Eurofound uses for the first time the expression "very atypical agreements" in order to make a distinction between these and the atypical agreements regulated both in our country, as well as at a European level (Eurofound, 2010). As for the arguments that brought these new employment forms to attention, in the area of individual labor agreements, they are mostly related to the need for flexibility entailed by the continuous economical changes, but are also a reaction to the rigidity of the regulations governing the standard employment relationships. For this specific reason, some authors consider them to be either "the expression of a request more and more volatile of the consumer's caprices" or ways to reduce the personnel expenses in an unpredictable business environment or ,the result of a contractual creativity meant to break the legal corset" (Dimitriu, 2016, p.126).

According to other authors, resort to flexible work arrangements depends directly on the needs of employers, and as such these atypical arrangements have emerged as strategies to adjust to the economic, technological and legislative changes shaping the labor market (Bercusson, 1996).

However, the domestic legislative context regarding the flexible employment options - as legal system having an interdependence relationship with the European legal system - is quite poor. Contractually speaking, the flexibility notion is often used by reference to the part-time agreement, 
to the agreement concluded for a determined period of time, to the labor agreement in which the activity is performed at home or to telework, even if, at a European level, a clear distinction is made between the well-known flexible labor agreements (part-time or telework) and the new flexible employment options (on call work, employee sharing contract, job sharing, interim-management, voucher based work, etc.) (Marica, 2019).

Considering the Romanian legislator's preference for the old-fashioned basic organization form in the form of labor agreement corroborated with the lack of legal framework regulating the varieties of flexible employment forms, a particular analysis of certain completely new contractual arrangements, otherwise popular in other legal systems, can prove to be useful for the internal legal practice. Among the diverse and heterogeneous atypical work arrangements (Eurofound, 2015) which have proliferated under other European legal systems, we address the interim management contract as a new employment arrangement.

The literature that deals with questions of work flexible arrangements, describes the interim-management concept as a flexible ,option of supplementing the enterprise management" - a flexible tool that offers a good option in balancing-out the aspects of time, costs, and quality relating to the human resources management. (Bruns, 2005, p. 18).

The main objective of our research is to demonstrate that the interim management employment contract is a contractual arrangement with great potential for development and implementation on a national scale, given the evolution of individual labor relationships towards increased flexibility. We have deemed it useful to analyze the ,interim management" concept and its implications for the labor market, by providing examples offered by comparative law, with legal systems having less restrictive regulations of interim management contracts.

This approach has a twofold relevance. On the one hand, it points out that domestic legislation maintains a rigid framework, lacking diversity with regard to flexible employment, and does not reflect the economic realities and the European trend towards increased flexibility. Thus, the present study aims to offer a theoretical contribution to the specialized literature on the perceived utility of this new concept, with a view to implementing and regulating it in Romania. On the other hand, it is well known that this contractual agreement has better potential for development than other non-standard employment arrangements, due to the better pay of interim managers and it slow precarity.

\section{Theoretical framework on interim management}

A new employment option amongst the flexible forms of work which can be found in the European labor environment is the interim-management agreement. As defined by some authors, this type of contractual arrangement, namely the interim-management agreement implies the temporary employment of an expert, usually specialized in crisis management, in order for that person to undertake express objectives of the company. In other words, the model offers a practical answer to a company's business situation/problem (Filosofova \& Karzunke, 2014). The duration of the agreement is a short one, of 6 to 9 months, during which the interim-managers shall have to help the company overcome the crisis situations. Generally, this type of agreement is not regulated by the labor legislation, as the interim-managers are not employees of the company, but service providers and their obligations is one of result, not of conduct (Ștefãnescu, 2017).

Some of the sensitive problems generated by the macro-economic instability specific to the modern economy is the one related to the growth of the companies' competitiveness. This fear is also related to the constant economic globalization. Under these circumstances, in order to face the challenges generated by the competition between companies, the great companies had to adapt to 
these changes, by taking certain measures that would contribute to the obtaining of various advantages, including by attracting professionals that would come up with solutions meant to lead to well-determined fast results (Filosofova \& Karzunke, 2014). One of the authors that state the above is Bajzikova, according to whom an important factor that could make a difference, from a competitiveness perspective, is the knowledge a person possesses or his/her expertise, as a good belonging to the employee, who is in fact the one deciding in who's favor his/her knowledge/ expertise shall be used (Bajzikova et al., 2013).

As in case of most non-standard forms of work, the interim-management agreement came as a result of the dynamism specific to the business environment, but also as a consequence of the flexibility need specific to the economic process. The model is associated, in various legal forms (either as a labor agreement, or as a commercial or civil agreement), to the appetite of the companies for fast and concrete measures. From this perspective, the doctrine offers various opinions. Some authors claim that there are certain factors that come to sustain the idea of interimmanagement, having in mind both the companies' desire and focus to make fast profits, as well as the constantly growing need for qualified management personnel (Inkson et al. 2001; Bruns \& Kabst, 2005). Other authors underline the importance of flexible hours for the management, which was proven to have a positive impact on the growth of the competitiveness and, of course, of the productivity and, if the flexibility of employment is important in the sphere of individual labor agreement, so is the employment system based on interim management (Russam, 2005).

Various studies that have dealt with the topic regarding the diversity of the new forms of work, which include interim-management, have come to the conclusion that the majority of them work based on the liberty of contract. This means that, from a labor law perspective, as well as the protection mechanisms it implies, those that perform their work based on totally new contractual arrangements are deprived of the protection provided by the law to the employees (Marica, 2019). One of the sensitive problems that comes with the new employment forms phenomenon is tied to the ambiguity of the applicable regulations, in the sense that the rights and obligations of the contractual relationship are not always clear. In the countries where the legislation regulate flexible contractual varieties, often discrepancies appear when it comes to interpreting the legal texts (ILO, 2016). The sympathizers of this idea argue that, most of the time, atypical workers render the activity based on a commercial or civil agreement, but depend entirely on a sole client or receive direct instructions regarding the performance of their tasks (this is what the literature calls selfemployment dependent), having serious consequences in the field of employees' protection.

The workers under flexible employment contracts often fail to enjoy the protection provided by labor legislation to other forms of employment, because most of these flexible agreements are not regarded as employment contracts but as agreements concluded on the basis of freedom of contract. (Dimitriu, 2016). The protection of such workers depends on one's own individual ability to negotiate, as is the case of interim managers who, under most legal systems, are considered as self-employed persons. Thus we think that as many flexible employment forms as possible should be included under the umbrella of labor law regulations concerning workers' protection.

\section{Methodology}

Research methodology consists in a comparative law analysis centered on interim management programs. Thus, this study investigates the situation of states whose legislation is oriented towards the development of interim-management models as a new forms of work - such as Germany, Czech Republic, and UK. Considering that this contractual model offers notable advantages in terms of flexibility, the conclusions of the research suggest that the introduction of the interim management 
contract in national labor law could also become an opportune solution for the practice of labor relations in Romania.

With the same purpose, of stressing the usefulness and benefits of adopting this atypical work arrangement in Romanian internal legislation, the research methodology has included a comparative analysis of the characteristics and implications of the interim-management scheme, by looking into the characteristics of other types of work accepted by the Romanian legislation, such as Temporary Work Agent or consulting contract.

\section{Discussion - Interim - management as a new type of employment}

However, in order to issue an opinion regarding the benefits of including this type of agreement in the internal legislations, some aspects need to be clarified, as follows:

\section{Main characteristics of interim-management}

In accordance with the definitions expressed in the specialized literature, the following general features of interim-management contract can be noted:

(a) Firstly, interim-management is a flexible contract based of temporary form of work due to the fact that a highly skilled manager is employed for a determined period of timp to come up with quick solutions to the company`s problems in crisis management (Bruns, 2005, p. 17).

(b) The literature makes a clear distinction between the interim-manager and the management consultant. The criteria to distinguish those two have as grounds the capacity of interimmanagers to train other people and to actively be involved in the reorganization of the company; these aspects do not characterize the traditional consultant. Moreover, the integration ratio is another differentiating factor; it has been reported that interim-managers are well-integrated, while the activity of management consultants is based on pure counseling (Eurofound, 2015; Filosofova \& Karzunke, 2014).

(c) The difference between top management personnel and interim-managers is also a strong differentiating point. While top managers are hired based on a labor agreement, concluded for an undetermined period of time, based on which they receive a monthly salary, interimmanagers perform their work based on a services agreement, in exchange of a fixed amount, which can vary between EUR 600 - EUR 1,500 per day. (Högman \& Pontusson, 2015).

(d) At a first glance, if one looks at its structure, the interim-management can be easily taken for temporary agency. But there are considerable differences between the two; first, the temporary personnel is under the authority and control of the employer. For instance, in Germany, the authority is exercised by the client with whom an employee leasing agreement has been concluded. In case of interim-managers, the control of the interim-manager is not transferred to the client, as the two parties conclude a civil agreement for the execution of a certain task. (Alewell et al., 2005).

\section{Interim-management - utility and uncertainty}

A very strong point of the whole system based on interim-management is that interim-managers are very motivated to be efficient and to achieve, in general lines, whatever they have undertaken based on the agreement, being responsible for both success and failure. In other words, the interimmanagers have the direct responsibility of their actions and bear the risk of not reaching the objective established and detailed within the relevant agreement; this means that their remuneration depends directly on their results (Dzwigol, 2020). In this respect, one of the opinions found in the relevant literature is very suggestive. Some authors (Dimitriu, 2016, p. 138) don't even include 
interim -management in the category of non-standards agreements that imply an uncertainty degree, due to the high remuneration of the interimmanagers. The topic is approached also by other authors that underline the fact that interimmanagers accept to perform this type of activity for a determined period of time, by taking certain business risks and waiving the protection offered to employees, especially because of the high remuneration level (Dzwigol, 2020).

Probably the biggest economic advantage behind the interim-management is related to the fact that it is often used during economic crisis, either when the restructuring of the company is taken into consideration or in order to temporary replace a manager who was dismissed or is suddenly absent, upon his/ her return/ replacement. As such, the company's ability to adapt to innovation and variety, with a focus on precise objectives, within a certain timeframe, becomes a strategy aimed at economic efficiency. More precisely, interim-management offers access to specialized knowledge, tailored on the flexibility need and excludes, from the company's perspective, the long-term commitments, as well as the burden to observe restrictive rules and regulations governing the labor agreement, with all its implications regarding its suspension, termination, dismissal, social protection. (Eurofound, 2015). For example, In Germany, even if the cost of an interim-manager exceeds by far the one of an internal manager, it is considered that the quality of the services performed by the interim-managers has undeniable advantages (Filosofova $\&$ Karzunke, 2014). From another perspective, we feel that the economic benefits on behalf of the company that come with the employment system based on interim management represent in fact disadvantages for the ones rendering this type of activities. In other words, depriving the workers of certain social security benefits (medical leaves, leaves, unemployment allowance, notice period, etc.), in the absence of a labor agreement, have onerous effects on interim-managers. In fact, the relevant literature underlined that fact that not anyone can be an interim-manager. The hypothesis based on which this opinion was issued is connected to the financial independence necessity of interim-managers and their capacity to financially support their families, as a result of both the fact that they do not benefit from an employment protection, acting as service providers, on one side, as well of the fact that they undertake the risk of not reaching the objectives, on the other side (Dzwigol, 2020). The relevant literature makes reference to this specific category of personnel and a certain psychosocial risk related to the stress that comes with the job insecurity, but also to a professional isolation of the respective persons, as they occupy unique positions in the company. (Eurofound, 2015).

\section{Comparative law elements}

The contractual arrangement based on interim-management, while still not very popular, is spread in many legal systems such as Germany, Holland, Czech Republic or UK. As it is appreciated for the flexibility elements it brings in the work relationships, the model has many advantages in the more and more diverse business sectors. For instance, in Germany, most of the interim-managers have previously been managers in fields such as sales and other interest areas that implied restructuring strategies at a company level (Bruns \& Kabst, 2005). In Germany, we also meet the mechanism on which the functioning type of employment is underlie, namely the implication of a Temporary workforce agency, but mention should be made that the professional managers are not employees of either the agency or the clients and they are considered self-employed (Alewell et al., 2005). Separate from the contractual form itself, the trend of this type of arrangements is an ascending one due to the continuously growing need for professional managers of the business environment; this aspect is also reflected by the satisfaction ratio of German companies when using this business model. Mention should be made that, in Germany, the number of interim-managers 
has grown from 7,000 in 2014 to 7,500 in 2015 and the most attractive fields of activity for the interim-management industry are IT, telecommunication, engineering or automotive (Filosofova \& Karzunke, 2014).

Interim-management is a flexible contractual arrangement which occupies a specific sector of the labor market as well in the Czech Republic. As in Germany's case, the temporary workforce agency plays a very important role in placing the interim-managers, based also on an agreement governed by the civil law. For example, the agreement of an interim-manager in the medical field contains, besides the well-defined objectives, certain aspects that regard the weekly work duration ( 28 hours), workplace, as well as the regime of the on call obligations. In addition, the triangular relationship between the agency, hospital and interim-manager with respect to the monitoring of the objectives is of the essence in case of this contractual model in the Czech Republic (Eurofound, 2015).

A new development of the interim-management in the individual labor relationships field can also be found in the UK or New Zealand. While in $U K$, most of the interim-managers are involved in the private sector, in New Zealand the flexibility and autonomy need, as well as the need to obtain additional revenues, seem to represent the strongest arguments that explain its popularity also amongst women. (Eurofound, 2015).

\section{Conclusions}

The particularities and utility of the employments system based on interim-management, as well the benefits it provides to the involved parties, have led to its continuous development on the European market. As previously mentioned, in the analyzed law systems, the implementation of interim-management is a strategic steak for the achievement of flexibility in work relationships. However, besides the fact that this contractual model answers the need for contractual flexibility and it offers high remunerations to the ones performing it, from the labor law perspective, some mentions need to be made. As such, regarding the short duration of this agreement, we consider that it increases instability and affects the stress level of the ones choosing this option, due to the unpredictability of their future. As we are addressing a civil agreement, the legal framework do not provide for the same level of security as in the traditional employment relationships. Even though the remuneration granted to the interim-managers is very high, interim managers feel the fear of losing their job, as well, and of not easily finding a different client. Moreover, the increasing European trend of those rendering such interim management service may trigger the more bitter competition between them which can materialize in the increase in the number of interimmanagers that have no job offers; this will easily lead to the increase of the already mentioned instability level.

Without any doubt, in order to keep up with the requirements of the participants and the technical and economic evolution, the internal legislation and the reaction to the flexibility need to be adapted to the new conditions and the improvement of the contractual framework by internally regulating interim-management can prove to be an opportune solution. But including this agreement in the labor legislation (by adopting a special law of by amending the Labor Code) and not leaving the negotiation to the sole discretion of the parties may allow the application of general fundamental labor law principles such as the ones regarding protection in case of interim-managers as well. Thus, the interpretation according to which interim management is eluding the labor law and social security legislation may remain groundless. 


\section{References}

Alewell, D., Bähring, K.T. (2005). Institutional Structures of the Flexible Assignment of Personnel between Enterprises. An Economic Comparison of Temporary Agency Work, Interim Management and Consulting, Management Revue, 16, 475-493.

Bajzikova, L., Sajgalikova, H., Wojcak, E., Polakova, M. (2013). Are flexible Work Arrangements Attractive Enough for Knowledge-intensive Bussinesses?, ProcediaSocial and Behavioral Sciences, 99, 771-783.

Bercusson, R. (1996). European Labour Law, Butterworths.

Bruns, J. \& Kabst, R. (2005). Interim-Management: A Paradox for Leadership Research?, Management Revue: The International Review of Management Studies, 16 (4), 512-524.

Bruns, J. (2005). Interim-Management- deployments in an innovation-context, Thesis on social sciences (Economics), Retrieved from: file:///C:/Users/flori/AppData/Local/Temp/bce9f4 cb9123402fb60f60272f1f8cf5-3.pdf.

Dimitriu, R. (2016). Dreptul muncii - Anxietăți ale prezentului. Rentrop \& Straton, București.

Dzwigol, H. (2020). Interim Management as a New Approach to the Company Management, Review of Business and Economics Studies, 8 (1), 20-26.

Eurofound (2010). Flexible forms of work: „,very atypical” contractual arrangements, Retrieved from: https://www.eurofound.europa.eu/publications/report/2010/flexible-forms-of-workvery-atypical-contractual-arrangements.

Eurofound (2015). New forms of employment, Publications Office of the European Union, Luxembourg, Retrieved from: https:/www.ioeemp.org/fileadmin/ioe_documents/publica tions/Policy\%20Areas/future_of_Work/EN/_2015-12-04_New_Forms_of_Employment Eurofound.pdf.

Filosofova, T., \& Karzunke, I. (2014). Interim Management: a new tool to enhance a company`s competitive performance under current global instability, Conference poceedings. $15^{\text {th }}$ International Scientific Conference, 155-159.

Hevestone, D. (2010). National Context and Atypical Employment, în International Sociology, 25, 315-347.

Högman, E. \& Pontusson, C. (2015). Interim Management \& Organisational Learning”, Master Thesis.

ILO (2016). International Labour Organisation, Nonstandard employment around the world.

Inkson, K., Heising, A., \& Rousseau, D.M. (2001). The interim manager: Prototype of the $21^{\text {st }}$ century worker?, Human Relations, 54(3), 259-284.

Russam, C. (2005). Flexible resourcing: the strategic case for interim management, Strategic Change, (14), 157-163. 